\title{
The tylosin biosynthetic cluster from Streptomyces fradiae: genetic organization of the left region
}

\author{
Roberto Fouces, Encarnación Mellado, Bruno Díez and José Luis Barredo
}

Author for correspondence: José Luis Barredo. Tel: +34987 895826. Fax : +34987895810 e-mail : jbarredo@antibioticos.it

Laboratorio de Ingeniería Genética, Antibióticos SA Avenida de Antibióticos 59-61, 24080 León, Spain

\begin{abstract}
The genetic organization of the left edge (tylEDHFJ region) of the tylosin biosynthetic gene cluster from Streptomyces fradiae has been determined. Sequence analysis of a $12.9 \mathrm{~kb}$ region has revealed the presence of 11 ORFs, 10 of them belonging to the biosynthetic cluster. The putative functions of the proteins encoded by these genes are as follows: peptidase (ORF1, ddcA), tylosin resistance determinant (ORF2, tIrB), glycosyltransferase (ORF3, tyIN), methyltransferase (ORF4, tyIE), ketoreductase (ORF5, tyID), ferredoxin (ORF6, tylH2), cytochrome P450 (ORF7, tyIH1), methyltransferase (ORF8, tyIF), epimerase (ORF9, tyIJ), acyl-COA oxidase (ORF10, tyIP) and receptor of regulatory factors (ORF11, tyIQ). The functional identification of the genes in the proposed tylosin biosynthetic pathway has been deduced by database searches and previous genetic complementation studies performed with tylosin idiotrophic mutants blocked at various stages in tylosin biosynthesis. The tIrB gene has been shown to be useful as a tylosin resistance marker in Streptomyces lividans, Streptomyces parvulus and Streptomyces coelicolor and the effect of tylF on macrocin depletion has been confirmed. A pathway for the biosynthesis of 6-deoxy-D-allose, the unmethylated mycinose precursor, involving the genes tyID, tylJ and tyIN is proposed.
\end{abstract}

Keywords: glycosyltransferase, ketoreductase, cytochrome P450, methyltransferase, mycinose

\section{INTRODUCTION}

Tylosin is a macrolide antibiotic used in veterinary medicine to treat infections caused by Gram-positive bacteria and as an animal growth promoter in the swine industry. It is produced by several Streptomyces species including S. fradiae (Seno et al., 1977), S. rimosus (Pape $\&$ Brillinger, 1973) and S. hygroscopicus (Jensen et al., 1964), but S. fradiae is the micro-organism of choice for its industrial production. As with other macrolides, the antibiotic activity of tylosin is due to the inhibition of protein biosynthesis by a mechanism that involves the binding of tylosin to the ribosome, preventing the formation of the mRNA-aminoacyl-tRNA-ribosome complex (Kageyama et al., 1971).

Abbreviations: MLS, macrolide-lincosamide-streptogramin B; PBP, penicillin-binding protein.

The GenBank accession number for the 12905 bp sequence reported in this paper is AF055922.
The presence of gene clusters is a common phenomenon in antibiotic-producing micro-organisms. The genes involved in the biosynthetic pathway of antibiotics such as erythromycin, clavulanic acid, cephamycin, actinorhodin, tylosin, nogalamycin, puromycin and daunorubicin are clustered in the chromosome of different Streptomyces species (Díez et al., 1997). Tylosin biosynthesis has been extensively studied by both physiological (Fishman et al., 1987; Baltz \& Seno, 1981, 1988) and genetic (Merson-Davies \& Cundliffe, 1994; Gandecha et al., 1997; Cox et al., 1997) approaches. From the results of co-synthesis studies with idiotrophic mutants blocked at different steps in tylosin biosynthesis, 13 different loci (tylA to tylM) have been mapped. As a result, the most probable pathway for tylactone conversion to tylosin has been deduced (Baltz et al., 1983) (Fig. 1): the biosynthetic pathway proceeds from two acetate, one butyrate and five propionate units to the tylactone moiety to which sugar residues are attached (Baltz \& Seno, 1981). The tylosin gene cluster extends over about $85 \mathrm{~kb}$ in the genome of $S$. fradiae; it 

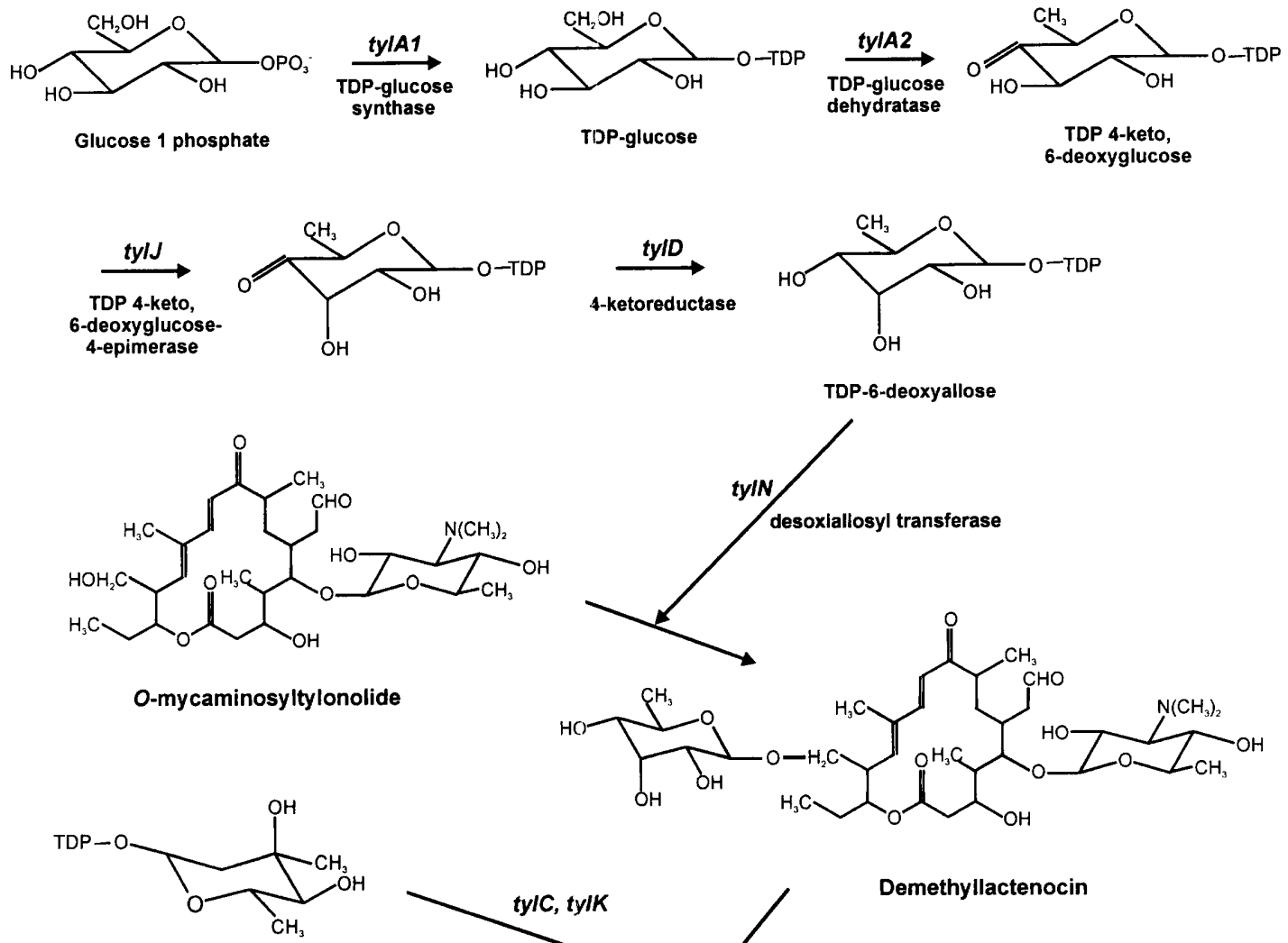

TDP-L-mycarose

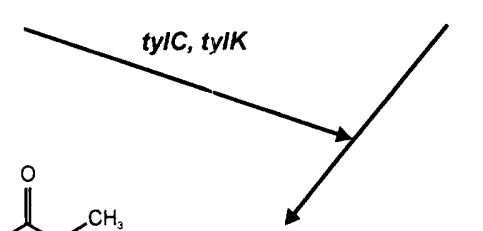

Demethyllactenocin

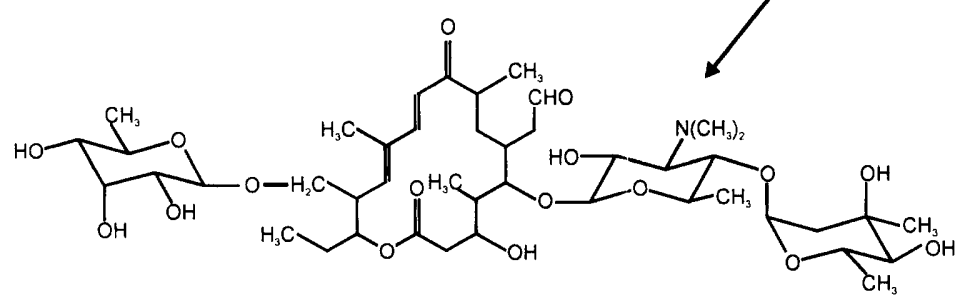

Demethylmacrocin
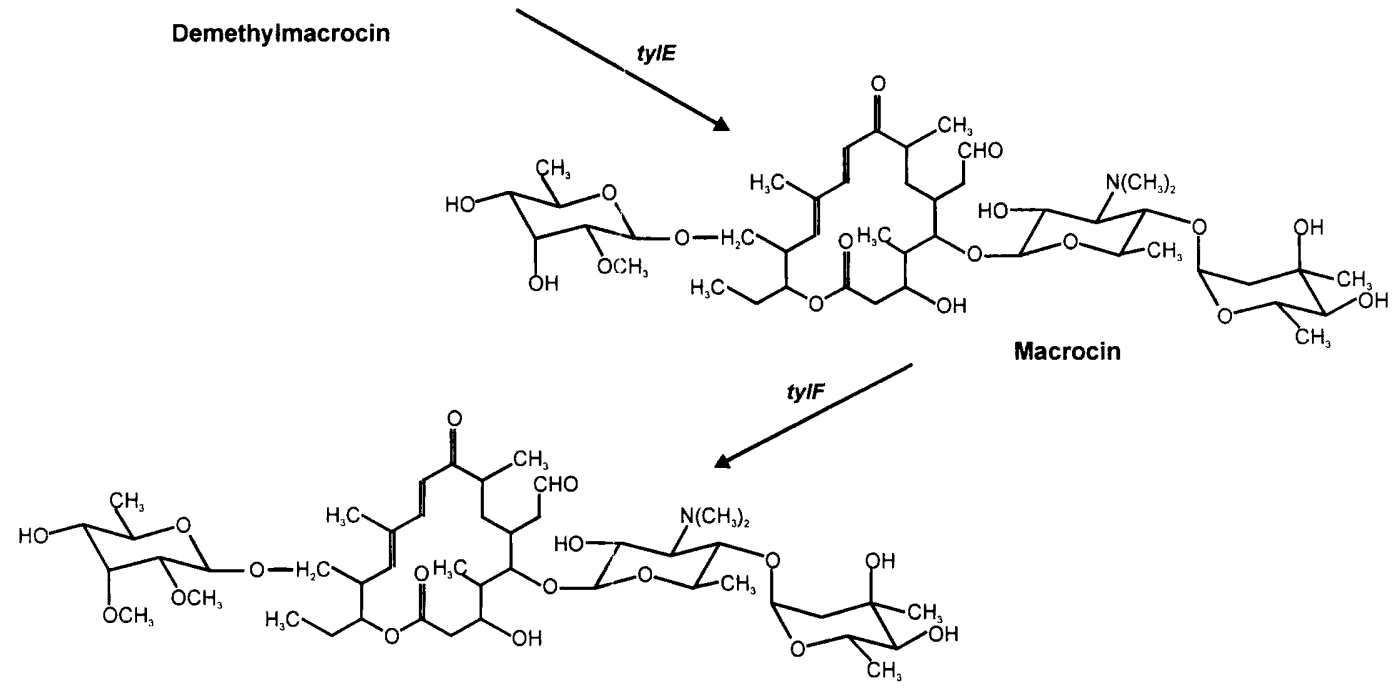

Tylosin

Fig. 1. Proposed biosynthetic pathway for mycinose synthesis and attachment to the tylosin molecule. A probable sequence of reactions leading to the mycinose moiety is shown. The involvement of the genes tylA1, tylA2, tylJ, tylD, tyIN, tylE and tyIF in the different steps is indicated. 
is flanked by the tylosin-resistance determinants $\operatorname{tr} B$ and $\operatorname{tir} C$, and can be divided into four different regions. The tyllBA region (right end) is located between the polyketide synthase genes $(t y l G)$ and the $t l r C$ resistance gene (Fig. 2). The nucleotide sequence of around $7 \mathrm{~kb}$ of this region contains five ORFs involved in early steps of the tylosin pathway: tyll encodes a cytochrome P450 responsible for macrolide ring hydroxylation at C-20; $t y l B$ is involved in the biosynthesis or addition of mycaminose; tylA1 and tylA2 encode two enzymes (TDPglucose synthase and $\delta$ TDP-glucose dehydratase) involved in the biosynthesis of TDP-4-keto-6-deoxyglucose, the biosynthetic precursor of tylosin sugars; and finally, ORF5 encodes a thioesterase (MersonDavies \& Cundliffe, 1994). Recently, the sequence of the tylLM region, located downstream of the $t y l G$ genes (Fig. 2), has been shown to include five ORFs (Gandecha et al., 1997): tlrD, encoding a tylosin-resistance determinant; $c c r$, encoding a crotonyl-CoA reductase that converts acetoacetyl-CoA to butyryl-CoA for use as a $\mathrm{C}_{4}$ extender unit during tylactone production; tylM1 and tylM2, encoding respectively an enzyme involved in $N$ methylation during mycaminose biosynthesis and a glycosyltransferase which adds mycaminose to the 5hydroxyl group of tylactone; and another ORF with an unknown function. The two remaining regions of the cluster, $t y l C K$ and $t y l E D H F J$, are located at the left edge (Fig. 2) and, according to complementation of mutants blocked in tylosin biosynthesis, genes involved in the last steps of the pathway should be located in this area (Baltz \& Seno, 1988). Prior to our study, the nucleotide sequence of these regions remained unknown and only the $t y l F$ and $t y l N$ genes had been described. The macrocin O-methyltransferase-encoding gene $(t y l F)$, which catalyses the final step in the tylosin pathway, had been partially sequenced (Fishman et al., 1987) and more recently, the $t y l N$ gene, encoding a glycosyltransferase involved in mycinose attachment to O-mycaminosyltylonolide, has been characterized (Wilson \& Cundliffe, 1998). The $t y l C$ and $t y l K$ genes seemed to be involved in the biosynthesis or attachment of mycarose, whereas tylD mutants accumulated demycinosyl tylosin (lacking mycinose) because they were blocked in the biosynthesis or addition of 6-deoxy-D-allose, a precursor of mycinose. tylJ and flanking DNA was also postulated to be involved in the biosynthesis of 6-deoxy-D-allose. tylE mutants accumulated demethylmacrocin and were unable to achieve the methylation of the 2-hydroxy position of the attached mycinose residue. $t y l \mathrm{H} \mathrm{mu}-$ tations resulted in accumulation of 23-deoxydemycinosyl tylosin and these mutants were unable to oxidize the C-23 methyl position of lactone (Baltz \& Seno, 1981).

Tylosin biosynthetic and self-resistance genes are closely linked in the genome of Streptomyces (Beckmann et al., 1989). S. fradiae has been reported to possess four tylosin resistance genes designated as $\operatorname{tr} A, t \operatorname{lr} B, \operatorname{tr} C$ and thrD. $\operatorname{tr}$ A (Zalacain \& Cundliffe, 1991; Cundliffe et al., 1993) and $t \operatorname{lrD}$ (Gandecha et al., 1997) encode methyltransferases responsible for methylation of a specific residue of adenine in the $23 \mathrm{~S} \mathrm{rRNA}$. The deduced amino acid sequence of $t r D$ shows homology to erythromycinresistance methylases (Gandecha et al., 1997). tlrC, located at the right end of the cluster (Fig. 2), is an ATPbinding protein probably constituting a subunit of a multicomponent export system for the energy-dependent efflux of tylosin from the producing organism (Rosteck et al., 1991). The presence of the $\operatorname{tr} B$ resistance gene at the left end of the biosynthetic cluster (Fig. 2) has also been reported (Birmingham et al., 1986; Birmingham \& Seno, 1988); it has been suggested that it may confer the MLS (macrolide-lincosamide-streptogramin B) resistance phenotype (Fujisawa \& Weisblum, 1981).

This paper describes the nucleotide sequence of the left edge of the tylosin gene cluster (Fig. 2), and discusses the putative functionality of the genes found in relation to the previously described $S$. fradiae idiotrophic mutants. This information can be used to guide strain improvement programmes, combining random mutagenesis and molecular cloning to optimize the yield of tylosin. An industrial-scale application based on the increase of the $t y l F$ gene dosage has been performed with highly productive strains of $S$. fradiae that accumulate relatively high levels of macrocin. Recombinant strains expressing higher levels of macrocin O-methyltransferase showed an improvement in tylosin yield (Solenberg et al., 1996; Baltz et al., 1997).

\section{METHODS}

Microbial strains, plasmids and microbiological procedures. $S$. fradiae ATCC 19609 was used as source of DNA. Escherichia coli DH5 (Hanahan, 1983) and E. coli WK6 (Kramer et al., 1984) were used for subcloning and ssDNA purification respectively. pBluescript I $\mathrm{KS}(+)$, pBluescript II $\mathrm{SK}(+)$ and $\mathrm{pBC} \mathrm{KS}(+)$ phagemids (Stratagene) were selected for routine subcloning and ssDNA preparation with the helper phage M13K07. pULVK99 (Chary et al., 1997) was utilized as E. coli-Streptomyces shuttle vector. Protoplast transformation of S. lividans, S. parvulus and S. coelicolor was performed according to Hopwood et al. (1985), whereas S. clavuligerus was transformed as described by García-Domínguez et al. (1987). Tylosin production was tested by flask fermentation according to previously described methods (Baltz \& Seno, 1981). Nucleic acid purification and manipulation were performed by standard procedures (Sambrook et al., 1990; Hopwood et al., 1985) with minor modifications. Plasmids were propagated in S. lividans ATCC 1326 prior to being introduced into $S$. fradiae ATCC 19609, S. parvulus DSM 40048, S. coelicolor DSM 40233 and S. clavuligerus ATCC 27064. Streptomyces transformants were selected on R 5 plates (Hopwood et al., 1985) supplemented with thiostrepton $(50 \mu \mathrm{g}$ $\mathrm{ml}^{-1}$ ), kanamycin $\left(50 \mu \mathrm{g} \mathrm{ml}^{-1}\right.$ ) or tylosin (from 100 to $500 \mu \mathrm{g}$ $\mathrm{ml}^{-1}$ depending on the strain).

DNA sequencing and Southern analysis. Sequencing clones were constructed with the Erase-a-Base kit (Promega), converted into ssDNA by standard procedures (Sambrook et al., 1989) and sequenced by the dideoxynucleotide method using Sequenase 2.0 (Amersham). Deazanucleotides and/or high annealing temperature $\left(42^{\circ} \mathrm{C}\right)$ were employed to eliminate compression problems. Southern blotting was carried out by 
standard procedures (Hopwood et al., 1985; Sambrook et al., 1989).

Construction of a S. fradiae genomic library. Total DNA from S. fradiae ATCC 19609 was isolated as previously described (Hopwood et al., 1985). Fragments of $17-22 \mathrm{~kb}$ were purified from Sau3AI partially digested DNA and ligated to $\lambda$ GEM12 phage vector (Promega) by standard procedures (Sambrook et al., 1989). Ligation products were packaged in vitro with the Gigapack II Gold kit (Stratagene), used to infect E. coli LE392 and plated to obtain about $5 \times 10^{4}$ p.f.u. Recombinant phages were amplified in liquid medium in order to purify their DNA (Sambrook et al., 1989).

Tylosin- and erythromycin-resistance assays in S. lividans. Tylosin (Tailan) was purchased from Elanco and erythromycin from Sigma. Expression of the $\operatorname{tr} B$ gene conferring the tylosin-resistance phenotype was achieved using the plasmid pALF250, consisting of pULVK99 with a $1.4 \mathrm{~kb}$ KpnI-SacII fragment carrying the $t / r B$ gene. This plasmid was introduced into S. lividans ATCC 1326, S. parvulus DSM 40048, S. coelicolor DSM 40233 and S. clavuligerus ATCC 27064. Antibiotic resistance tests of these Streptomyces species were performed in R5 medium supplemented with either $0-3500 \mu \mathrm{g}$ tylosin $\mathrm{ml}^{-1}$ or $0-200 \mu \mathrm{g}$ erythromycin $\mathrm{ml}^{-1}$.

Computer analysis of sequences. Sequence analyses were performed with Dnastar and Winstar packages, including the following programs: Mapseq for restriction analysis, Geneplot for ORF location, Geneman for database searching and Megalign for alignment. Alignments to determine protein similarities were performed using the CLUSTAL method. Comparisons of the deduced polypeptides were furthermore accomplished using the FASTA and T-FASTA programs against the SWISS-PROT and NBRF-PIR databases.

\section{RESULTS AND DISCUSSION}

\section{Molecular cloning of the tylosin gene cluster}

In order to isolate the tylosin gene cluster, a $S$. fradiae library was constructed and screened with the oligonucleotide 5' GCTCGATGTAGAGATCG 3' designed according to the nucleotide sequence of the $5^{\prime}$ region of the previously described $t y l F$ gene (Fishman et al., 1987). After three purification cycles, eight recombinant phages were characterized by restriction mapping and Southern analysis. All the phages shared common restriction fragments corresponding to the same genomic region. An $11.5 \mathrm{~kb} \mathrm{Sacl}$ fragment was purified and subcloned in pBluescript I KS $(+)$ producing the plasmid pALF1A (Fig. 2). Likewise, a PvuII fragment including a portion of the phage vector DNA was purified. The genomic fragment (around $16 \mathrm{~kb}$ ) was subcloned in pBluescript II SK $(+)$, generating the plasmid pALF2A (Fig. 2). Using the above-mentioned oligonucleotide as a probe, the $t y l F$ gene was located in $5.7 \mathrm{~kb} \mathrm{BamHI}$ and $4.1 \mathrm{~kb}$ Bam HI-BglII fragments.

To construct sequencing clones, several DNA fragments of the left edge of the tylosin gene cluster were subcloned in pBluescript $\mathrm{I} \mathrm{KS}(+)$ and $\mathrm{pBC} \mathrm{KS}(+):(\mathrm{I})$ a $5 \cdot 5 \mathrm{~kb}$ $B g / I I$ fragment generating pALF17 and pALF18; (II) a $5.7 \mathrm{~kb} \mathrm{BamHI}$ fragment including the $t y l F$ gene and generating pALF32 and pALF33; (III) a $1.0 \mathrm{~kb}$ BamHI fragment generating pALF13 and pALF15; and (IV) a $2.1 \mathrm{~kb}$ BamHI fragment generating pALF14 and pALF20. Afterwards, pALF17 and pALF18 were digested with $\mathrm{Bam} \mathrm{HI}$ and $S a C \mathrm{I}$ and the resulting fragments were subcloned in pBluescript I KS(+) to yield pALF71, pALF72, pALF73, pALF74, pALF76 and pALF77. Similarly, pALF32 was digested with BamHI and BglII and the resulting fragments $(4 \cdot 1 \mathrm{~kb}$ and $165 \mathrm{bp})$ were subcloned in pBluescript $\mathrm{I} \mathrm{KS}(+)$ generating pALF2, pALF10 and pALF21 (Fig. 2). The above-mentioned plasmids were treated with the Erase-a-Base kit, generating sequential deletions of about $300-500 \mathrm{bp}$.

\section{Nucleotide sequence determination of the left edge of the tylosin gene cluster}

A total of 12905 bp of DNA, spanning the tylEDHFJ region of the tylosin biosynthetic cluster, was sequenced. Computer analysis of the sequence using the Geneplot program revealed the presence of 11 complete ORFs, named from ORF1 (left) to ORF11 (right) (Fig. 2). All the ORFs detected showed the typical biased codon usage of Streptomyces genes (Bibb et al., 1984) and a mean $\mathrm{G}+\mathrm{C}$ content of $71 \cdot 8 \mathrm{~mol} \%$. Whereas ORF2, ORF8, ORF9 and ORF11 were oriented from left to right, ORF1, ORF3, ORF4, ORF5, ORF6, ORF7 and ORF10 were transcribed in the opposite direction. The close proximity of ORFs $3-7$ and 8-9 suggested two potential co-transcription units: ORFs 3-7 were spaced 45, 17, 0 and 35 bp and ORFs 8-9 were 36 bp apart (Fig. $3)$. The presence of three bidirectional promoter regions between ORFs 1 and 2 (356 bp), ORFs 7 and 8 (263 bp) and ORFs 10 and 11 (346 bp) is proposed.

\section{Deduced products of the sequenced ORFs}

In order to ascertain the putative functions of the previously determined ORFs, the deduced amino acid sequences were compared to the protein databases sWISS-PROT and NBRF-PIR. In the light of previous work on the genetics of tylosin biosynthesis and database search results, a function is proposed for each ORF. The results are summarized in Table 1.

ORF1 (ddcA). The predicted product (398 amino acid residues, $42.6 \mathrm{kDa}$, pI 9.7) showed the highest similarity $(31.4 \%)$ to an extracellular D-endopeptidase from $\mathrm{Bac}$ illus cereus with $\beta$-lactamase activity against ampicillin and penicillin G (Asano et al., 1996). Lower similarities were found to a serine DD-peptidase from Streptomyces R61 (27.4\%) (Duez et al., 1987) and a class 4 penicillinbinding protein (PBP) $(19 \cdot 4 \%$ ) (Coque et al., 1993). The sequence ${ }^{89}$ FRIGSLTK ${ }^{98}$ agrees with the consensus motif FXXXSXXK found in class A $\beta$-lactamases (Table 2). This gene, named $d d c A$, may play a role in the transpeptidation reaction of the peptide intermediate in peptidoglycan biosynthesis.

ORF2 (t/rB). The deduced amino acid sequence $(280$ residues, $30.4 \mathrm{kDa}$, pI 8.1 ) showed high similarity $(50.4 \%)$ to the mycinamicin-resistance determinant 


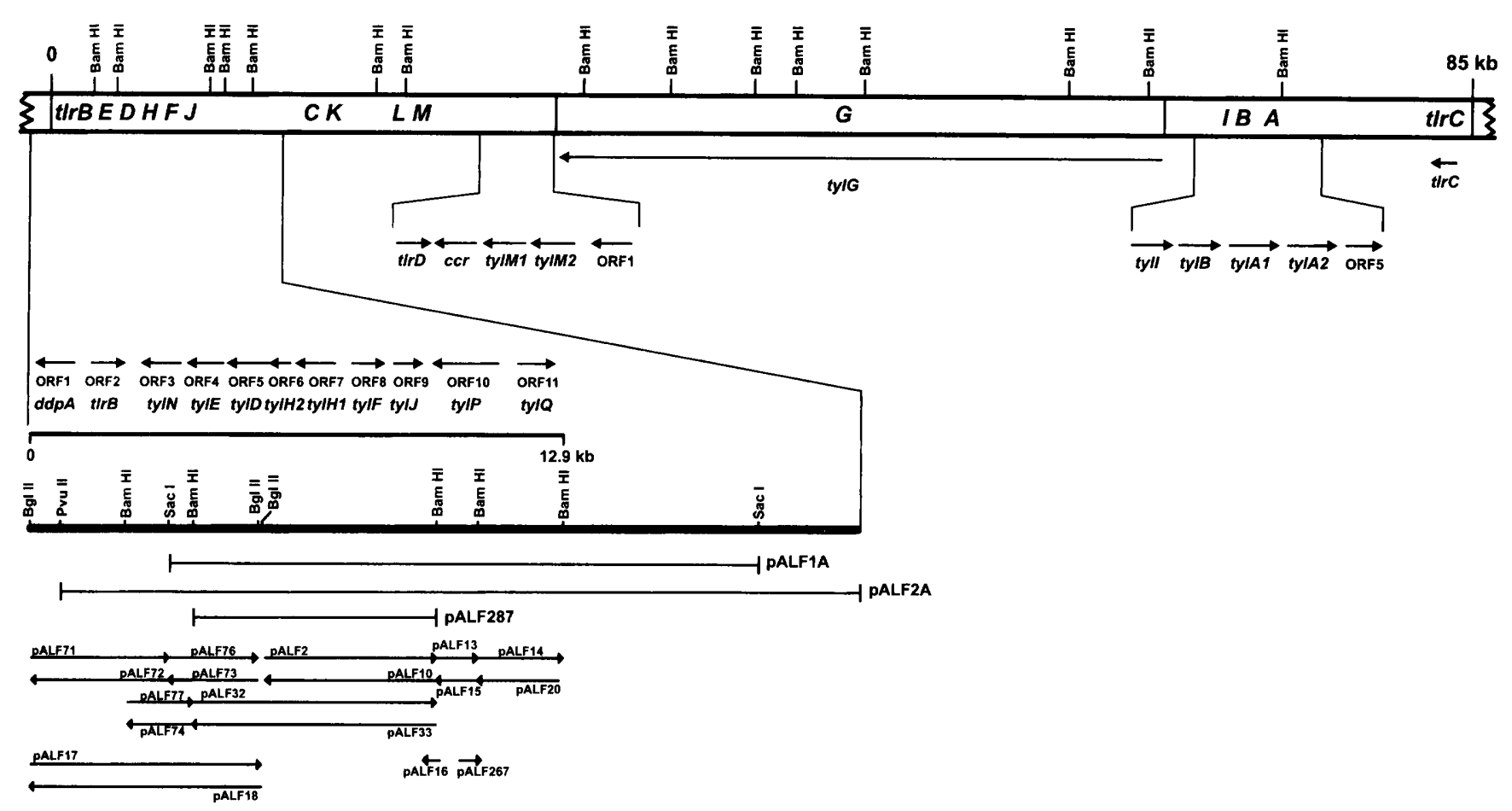

Fig. 2. Genetic map of the tylosin biosynthetic gene cluster. The region described in this work, including the genes ddpA, tIrB, tylN, tylE, tylD, tylH2, tylH1, tylF, tylJ, tylP and tylQ, is shown in greater detail. The restriction map of the $12.9 \mathrm{~kb}$ sequenced is marked as a thick line. Plasmids used in this work are indicated as pALFs. The ORFs revealed by Geneplot analysis and the direction of transcription are shown by arrows. The regions ty/LM and ty/IBA, and the genes ty/G and $t / r C$ (Merson-Davies \& Cundliffe, 1994; Gandecha et al., 1997; Rosteck et al., 1991), are also indicated.
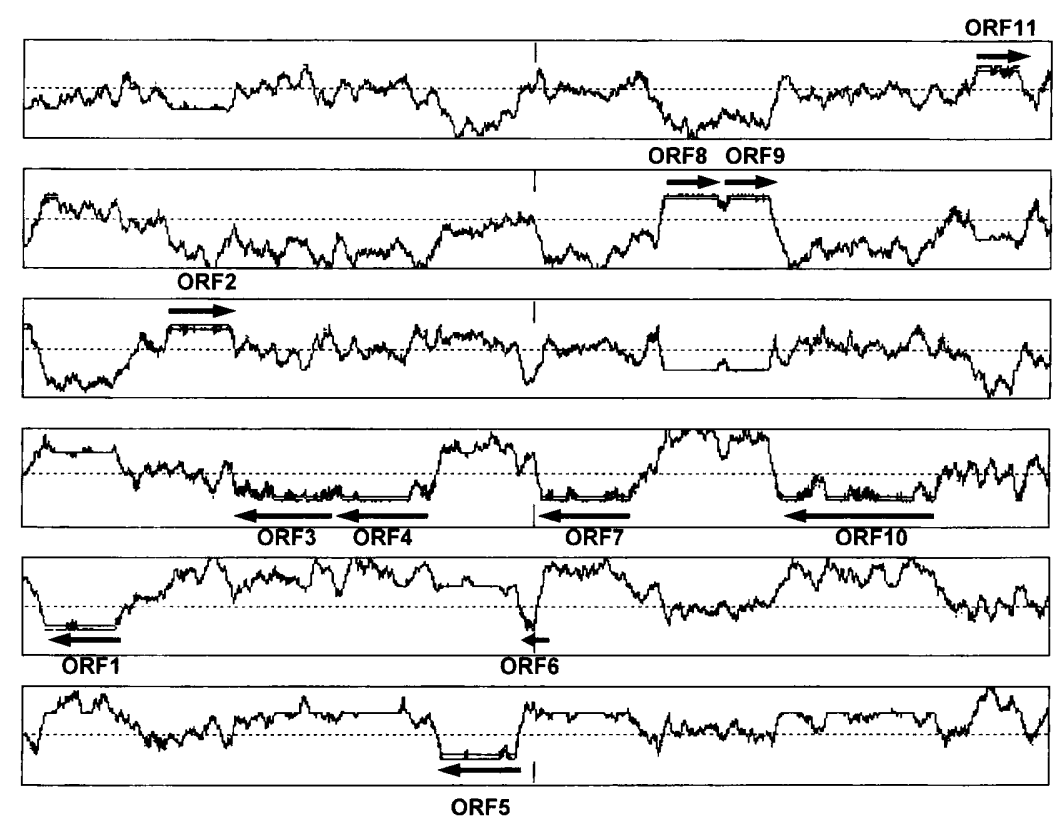

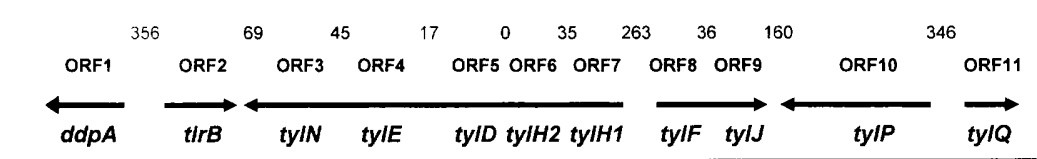

Fig. 3. Geneplot analysis revealing the ORFs in the $12905 \mathrm{bp}$ sequenced region. The putative transcriptional units are indicated by arrows. Co-transcription of ORFs $3-7$ and ORFs $8-9$ is proposed. The numbering above the ORFs indicates spacing in bp between each pair. encoded by the myrA gene from Micromonospora griseorubida (Fig. 4). The myrA gene confers both mycinamicin and tylosin resistance upon $S$. lividans
(Inouye et al., 1994a). The deduced products of myrA and $\operatorname{tr} B$ do not show significant similarity to other antibiotic-resistance proteins in the databases. The 
Table 1. Putative products and deduced functions of the genes analysed in this work

\begin{tabular}{|c|c|c|c|c|c|}
\hline ORF & Gene & $\begin{array}{c}\text { Product } \\
\text { size } \\
(\mathbf{k D a})\end{array}$ & Putative function & $\begin{array}{c}\text { Gene with } \\
\text { high } \\
\text { similarity }\end{array}$ & Reference \\
\hline ORF1 & $d d c A$ & $42 \cdot 6$ & Carboxypeptidase & $a d p$ & Asano et al. (1996) \\
\hline ORF2 & $t \operatorname{lr} B$ & $30 \cdot 4$ & $\begin{array}{l}\text { Tylosin resistince } \\
\text { determinant }\end{array}$ & myrA & Inouye et al. (1994a) \\
\hline ORF3 & $t y l N$ & $46 \cdot 6$ & Glycosyltransferase & $s g t$ & Warnecke et al. (1997) \\
\hline ORF4 & tylE & $43 \cdot 2$ & Methyltransferase & ORFY & Ylihonko et al. (1996) \\
\hline ORF5 & tylD & $36 \cdot 0$ & 4-Ketoreduct:se & eryBIV & Gaisser et al. (1997) \\
\hline ORF6 & tylH2 & $8 \cdot 2$ & Ferredoxin & soyB & Trower et al. (1992) \\
\hline ORF7 & tylH1 & $45 \cdot 5$ & Cytochrome P450 & suac & Omer et al. (1990) \\
\hline ORF8 & $t y l F$ & $28 \cdot 6$ & Methyltransferase & $m y c F$ & Inouye et al. $(1994 b)$ \\
\hline ORF9 & tyl] & $22 \cdot 8$ & Epimerase & $\operatorname{str} M$ & Pissowotzki et al. (1991) \\
\hline ORF10 & tylP & $71 \cdot 5$ & Acyl-CoA oxidase & aco & GenBank AF013216 \\
\hline ORF11 & tylQ & $24 \cdot 7$ & Receptor of butyrolactones & far $A$ & Waki et al. (1997) \\
\hline
\end{tabular}

Table 2. Conserved motifs in PBPs

Motif I corresponds to the $\beta$-lactamase active centre; motifs II and III are secondary elements present in PBPs.

\begin{tabular}{|c|c|c|c|c|}
\hline Micro-organism & Gene & Motif I & Motif II & Motif III \\
\hline Streptomyces fradiae & $d d c A$ & ${ }^{91}$ ERIGSLTK ${ }^{98}$ & ${ }^{198}$ YSNT $^{201}$ & ${ }^{351} \mathrm{FHGG}^{354}$ \\
\hline Bacillus cereus & $a d p$ & ${ }^{100}$ FRIGSVTK ${ }^{107}$ & ${ }^{201}$ YSNT $^{204}$ & ${ }^{341} \mathrm{GHGG}^{344}$ \\
\hline Streptomyces lividans & DD-Peptidase & ${ }^{89}$ FRVGSVTK ${ }^{96}$ & ${ }^{191}$ YSNT $^{193}$ & ${ }^{328} \mathrm{GHTG}^{331}$ \\
\hline Mycobacterium tuberculosis & $m t c Y$ & ${ }^{88}$ FRNGAVA I ${ }^{95}$ & ${ }^{188} \mathbf{Y} A H \mathbf{T}^{191}$ & ${ }^{339} \mathrm{GHWL}^{341}$ \\
\hline Nocardia lactamdurans & $p b p 4$ & ${ }^{56} \mathbf{F} Q S G S V A K^{63}$ & ${ }^{152} \mathbf{Y} \operatorname{CST} \mathbf{T}^{155}$ & ${ }^{301} \mathrm{GHDG}^{304}$ \\
\hline
\end{tabular}
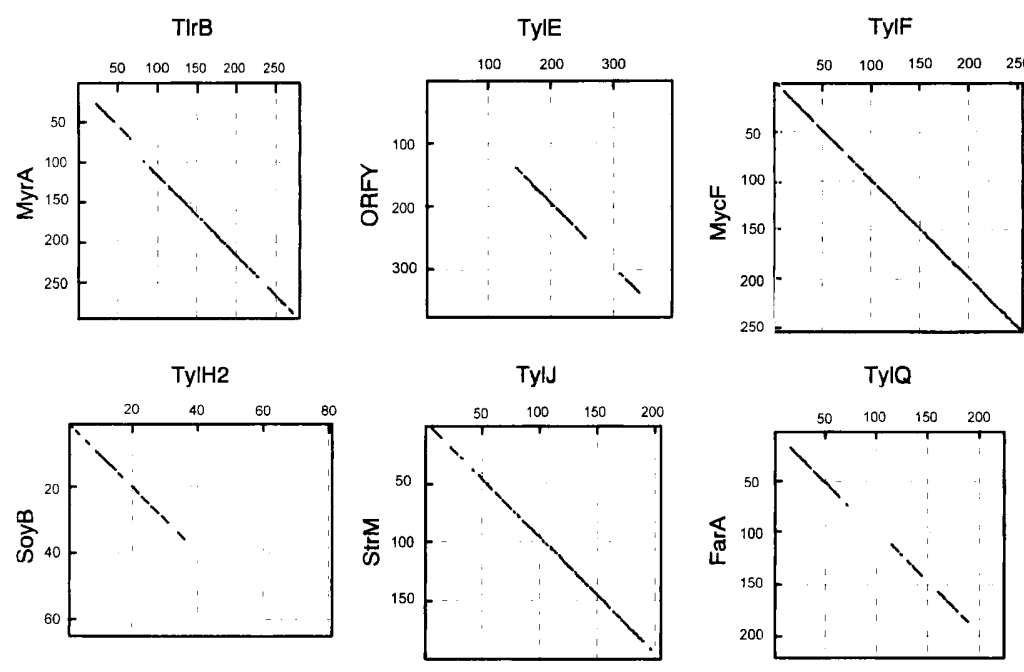

Fig. 4. Dot-plot analysis of six tylosin
biosynthetic polypeptides versus their similar
proteins using the program Dotplot with a
window size of 30 and a percentage match
of 50 . The following proteins were analysed:
TlrB versus MyrA from M. griseorubida, TylE
versus ORFY product from S. nogalater, TylF
versus MycF from $M$. griseorubida, TylH2
versus SoyB from S. griseus, TylJ versus StrM
from S. glaucescens and TylQ versus FarA
from Streptomyces sp.

myrA gene does not belong to the MLS resistance phenotype family since it is unable to confer resistance to erythromycin (Inouye et al., 1994a), and, as will be discussed later, the $\operatorname{tr} B$ gene behaved in a similar way when it was expressed in S. lividans and S. parvulus. The plasmid pALF250 carrying the $\operatorname{tr} B$ gene was able to confer tylosin resistance upon S. lividans, S. parvulus and $S$. coelicolor, whereas no resistance could be detected when the same plasmid was introduced into $S$. clavuligerus. The $\operatorname{tr} B$ gene has proved to be a useful resistance marker for transformation experiments in several Streptomyces spp.

The clustering of biosynthetic and resistance genes for the same antibiotic has been reported in several microorganisms (Epp et al., 1987; Distler et al., 1985; 
Richardson et al., 1987). Four tylosin-resistance genes named $\operatorname{tr} A$ (Zalacain \& Cundliffe, 1991), $t \operatorname{lr} B$ (Birmingham et al., 1986; Birmingham \& Seno, 1988), tlrC (Rosteck et al., 1991) and tlrD (Gandecha et al., 1997) have been isolated and phenotypically characterized from tylosin-producing strains of $S$. fradiae. The presence of two of these resistance genes $(t \operatorname{lr} B$ and $t \operatorname{lr} C)$ in the vicinity of the tylosin cluster suggests a functional interaction among them.

ORF3 (tyIM). The deduced polypeptide (422 residues, $46.6 \mathrm{kDa}$, pI 8.0 ) displayed similarity to glycosyltransferases from different sources, including a UDPglucose sterol-glucosyltransferase from Arabidopsis thaliana $(24 \cdot 2 \%$ ) (Warnecke et al., 1997) and a glycosyltransferase from the vancomycin producer Amycolatopsis orientalis $(23.3 \%$ ) (Solenberg et al., 1997). As occurs with the product of the tylM2 gene, located in the tylLM region of the tylosin cluster from $S$. fradiae (Gandecha et al., 1997), slight similarity was detected to other glycosyltransferases from antibiotic-producing Streptomyces spp. A recent report by Wilson \& Cundliffe (1998) describes the characterization and targeted disruption of the $t y l N$ gene from $S$. fradiae encoding a glycosyltransferase (GenBank A J005397). In the tylosin biosynthetic pathway proposed by Baltz et al. (1983), the synthesis of the macrolide proceeds by sequential glycosyltransfer reactions, each catalysed by a specific transferase. Previous complementation experiments (Fishman et al., 1987; Baltz \& Seno, 1981) revealed that the products of the genes grouped in the region studied in the present work are involved in reactions leading to biosynthesis and/or addition of the mycinose moiety to the aglycone. According to Wilson \& Cundliffe (1998), the glycosyltransferase encoded by $t y l N$ is responsible for the transfer of the 6-deoxy-D-allose, the unmethylated precursor of mycinose, to the tylactone ring. The ORF3 corresponds to the reported $t y l N$ gene, but significant differences have been found at the sequence level. (1) The ATG translation start codon is different because ORF3 includes 62 additional amino acids in the $\mathrm{N}$-terminal region. Both the length and $\mathrm{N}$-terminal sequence of the ORF3 deduced protein agree better with other transferases, and codon preference analysis with the Geneplot program shows a clear bias in this region. (2) A frame shift between amino acids 341 and 359 (corresponding to residues 278-296 in the sequence A J005397) is detected. In this case, the ORF3 product agrees better in this region with other transferases, and Geneplot analysis shows the frame shift in the sequence AJ005397. (3) There are 12 additional single-residue disagreements at the amino acid sequence level.

ORF4 (tyIE). The deduced amino acid sequence $(395$ residues, $43.2 \mathrm{kDa}$, $\mathrm{pI} 5 \cdot 5$ ) showed $51.8 \%$ similarity to the unknown product encoded by ORFY of the nogalamycin biosynthetic gene cluster from Streptomyces nogalater (Ylihonko et al., 1996) (Fig. 4) and a remote similarity to the $m d m C$ gene from the midecamycin producer Streptomyces mycarofaciens, encoding a 4-Omethyltransferase (Hara \& Hutchinson, 1992). According to previous complementation studies using idio- trophic mutants (Fishman et al., 1987; Baltz \& Seno, 1981), and characterization of the activity of demethylmacrocin-O-methyltransferase (Kreuzman et al., 1988), the $t y l E$ locus was proposed to be located in this group of genes and to be involved in the methylation of the 2$\mathrm{OH}$ position of the attached 6-deoxy-D-allose residue. The ORF4 location would fit the phenotype of $t y l E$ mutants; however similarity to $O$-methyltransferases, including the $t y l F$ product (macrocin O-methyltransferase) is minimal. Furthermore, the consensus binding region common to $\mathrm{O}$-methyltransferases is lacking in ORF4 and $m d m C$ (Ingrosso et al., 1989). Nevertheless, Ingrosso et al. (1989) analysed a series of $S$-adenosylmethionine-dependent methyltransferases observing that, despite sequence divergence, a glycinerich motif (VLE/DXGXGXG) involved in $S$-adenosylmethionine binding was conserved. As in the products of ORFY from $S$. nogalater, $t y l M 1$ and $t y l F$ from $S$. fradiae, and $m d m C$ from $S$. mycarofaciens, the sequence ${ }^{196}$ VLEIGIGGY ${ }^{204}$ was found in the product of $t y l E$.

ORF5 (ty/D). The deduced protein ( 336 residues, $36.0 \mathrm{kDa}$, pI 8.8) showed significant sequence identity to glucose 4,6-dehydratases from various organisms as does the deduced product of eryBIV from Saccharopolyspora erythraea (Gaisser et al., 1997). Since an eryBIV deletion mutant synthesizes erythromycins containing a 4-keto derivative of mycarose, EryBIV is likely to be the 4ketoreductase required for mycarose biosynthesis. In spite of the divergence present in the primary structure of sugar oxidoreductases, all members have two rigorously conserved motifs involved in cofactor binding: GXXGXXG and YXXXKXXXD/E. Motif I is located within the first 20 residues of their $\mathrm{N}$-termini, resembling the Rossmann fold characteristic of nucleotide-binding sites (Wierenga \& Hol, 1983). Motif II is about 100 residues downstream of motif $I$, and tyrosine and lysine residues are involved in cofactor binding (Bauer et al., 1992). Similar motifs are also present in NDP sugar 4,6dehydratases (Table 3 ). In the ORF5 product motif I was located at the N-terminal edge $\left({ }^{16} \mathrm{GALGFIG}^{22}\right)$ and motif II was located 141 residues downstream $\left({ }^{163}\right.$ YVLSKIFCE $\left.^{171}\right)$. Likewise, in EryBIV there are 120 residues between the two motifs (Table 3). This suggests that, as eryBIV encodes a 4-ketoreductase involved in mycarose biosynthesis, ORF5 could be involved in a similar ketoreductase step for mycinose biosynthesis.

Another gene encoding a TDP-glucose dehydratase, designated $t y l A 2$, located in the $t y l I B A$ region of the tylosin cluster of $S$. fradiae, has also been described (Merson-Davies \& Cundliffe, 1994). According to these authors, tylA2 is responsible for the formation of TDP4-keto-6-deoxy-D-glucose, a common intermediate in the biosynthetic pathway of the three tylosin sugars: mycinose, mycarose and mycaminose. This assignment was made according to the phenotype of $t y l A$ mutants, which are defective in the biosynthesis of all three deoxysugars. In contrast, $t y l D$ mutants are blocked only in mycinose biosynthesis. In the present work, the ORF5 encoding a putative 4-ketoreductase activity which could direct the synthesis of 6-deoxy-D-allose, the 
Table 3. Conserved motifs in glucose dehydratases

Two rigorously conserved motifs involved in cofactor binding are shown.

\begin{tabular}{|c|c|c|c|}
\hline Organism & Gene & Motif I & Motif II \\
\hline Streptomyces fradiae & $t y l D$ & ${ }^{16}$ GAIGFIG ${ }^{22}$ & ${ }^{163} \mathbf{Y V L S K I F C E}{ }^{171}$ \\
\hline Streptomyces fradiae & tylA2 & ${ }^{7}$ GGAGFIG ${ }^{13}$ & ${ }^{151}$ YAATKAASD ${ }^{159}$ \\
\hline Arabidopsis thaliana & d18 & ${ }^{125}$ GGA GFVG $^{131}$ & ${ }^{261}$ YDEGKRTAE ${ }^{269}$ \\
\hline Arabidopsis thaliana & T30b22.4 & ${ }^{127}$ GGP GFV $^{133}$ & ${ }^{258} \mathbf{Y}$ DEGKRTAE $\mathbf{E}^{\mathbf{2 6 6}}$ \\
\hline $\begin{array}{l}\text { Methanobacterium } \\
\text { thermoautotrophicum }\end{array}$ & $m t h 380$ & ${ }^{10}$ GGI,GFIG $\mathbf{G}^{16}$ & ${ }^{145}$ YAVSKVTGE ${ }^{153}$ \\
\hline Synechocystis sp. & $\mathrm{rfbB}$ & ${ }^{26}$ GGAGFIG ${ }^{32}$ & ${ }^{162}$ YDEGKRVAE ${ }^{170}$ \\
\hline Synechocystis sp. & ORFslr0583 & ${ }^{7}$ GGTGFLG ${ }^{13}$ & ${ }^{130}{ }^{3}$ AMTKRML $\mathbf{Y}^{138}$ \\
\hline Saccharopolyspora erythraea & eryBIV & ${ }^{16}$ GASGEVG ${ }^{22}$ & ${ }^{142}$ YAQQRTEA $\mathbf{E}^{150}$ \\
\hline Streptomyces violaceoruber & graE & ${ }^{7}$ GAAGEIG ${ }^{13}$ & ${ }^{149} \mathbf{Y A A S K A S T} \mathbf{T}^{157}$ \\
\hline $\begin{array}{l}\text { Streptomyces } \\
\text { viridochromogenes }\end{array}$ & aviE & ${ }^{18}$ GGFGFIG ${ }^{24}$ & ${ }^{156}$ YAASKAGGD ${ }^{164}$ \\
\hline Streptomyces griseus & strE & ${ }^{9}$ GAAGFIG ${ }^{15}$ & ${ }^{150}$ YSASKASGD ${ }^{158}$ \\
\hline
\end{tabular}

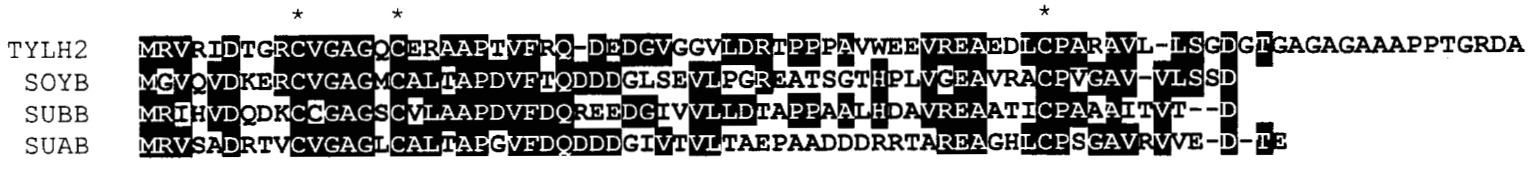

Fig. 5. Alignment of amino acid sequences of ferredoxins encoded by the following genes: tylH2 from $S$. fradiae, soy $B$ from S. griseus, subB from S. griseolus and $s u a B$ from S. griseolus. The alignment was performed with the program Megalign using the CLUSTAL method and the following parameters: ktuple 1, gap penalty 3 and window 5 . Three critical Cys residues, conserved in all ferredoxins and involved in iron chelating, are marked by asterisks; they are located at positions 10, 16 and 54 of the $\mathrm{Tyl} \mathrm{H} 2$ polypeptide.

mycinose precursor, has been found in the map position of $t y l D$ locus (related to mycinose biosynthesis). We propose ORF5 to be the tylD gene involved in mycinose biosynthesis, as previously characterized by complementation studies of tylD mutants (Fishman et al., 1987, (Fig. 1).

ORF6 (ty/H2). This gene has the highest $\mathrm{G}+\mathrm{C}$ percentage $(77.7 \mathrm{~mol} \%)$ among the ORFs analysed in this work and encodes a predicted 81-residue polypeptide (molecular mass $8 \cdot 2 \mathrm{kDa}, \mathrm{pI} 4 \cdot 4$ ). Database searches showed high similarity to $[3 \mathrm{Fe}-4 \mathrm{~S}]$-type ferredoxins from several Streptomyces spp. and also to the N-terminal end of both a [4Fe-4S]-type ferredoxin from Rbodococcu; fascians (Crespi et al., 1994) and a homologous thioesterase from S. griseus (Criado et al., 1993). The closes similarity $(43 \cdot 1 \%)$ was found to the $\operatorname{soyB}$ gene from $S$. griseus (Trower et al., 1992) (Fig. 4), encoding a ferredoxin-like protein, suggesting this function for the ORF6 product. Additional support comes from the high degree of conservation of the three critical cysteine residues necessary for chelating iron at positions 10,16 and 54 (Fig. 5). Ferredoxins are small acidic electrontransfer proteins that contain $\mathrm{Fe}-\mathrm{S}$ clusters attached to the polypeptide via cysteine residues. Little is known about the in vivo assembly of these clusters and the role that the sequence motif plays in that process (Bruschi \&: Guerlesquin, 1988). As in several other organisms, this gene, which we designated as $t y l H 2$, is located downstream of and adjacent to ORF7 (encoding a cytochrome; see below). Hence, these two genes form an oxidoreduction system, probably implicated in the C-23 ring oxidation during tylosin biosynthesis.

ORF7 (tylH1). The deduced protein $(420$ residues, $45.5 \mathrm{kDa}, \mathrm{pI} 5 \cdot 0$, showed close similarities to cytochrome P450 proteins encoded by the genes suaC $(40.9 \%)$ from Streptomyces griseolus (Omer et al., 1990) and sca-2 $(39.5 \%$ ) from Streptomyces carbophilus (Watanabe et al., 1995). In most actinomycetes, a protein with monooxygenase activity is encoded in the vicinity of an iron-sulfur redox protein (O'Keefe \& Harder, 1991). The alignment of the ORF7 product with other reported cytochromes, including the CYP450 encoded by the tyll gene of the tylosin cluster responsible for C-20 ring oxidation of O-mycaminosyltylactone (Merson-Davis \& Cundliffe, 1994), is shown in Fig. 6. The residues forming the oxygen-binding site $\left({ }^{259} \mathrm{AGHETT}^{264}\right)$ in helix $\mathrm{I}$, including the invariant $\mathrm{G}^{260}$ and $\mathrm{T}^{263}$ residues common to all cytochrome $\mathrm{P} 450$ proteins, were also present. Furthermore, a very strong conservation of the residues that constitute the haem-binding domain ${ }^{362}$ FGYGPHQCLGQ ${ }^{372}$ is present. This domain is thought to be involved in the folding of the haembinding pocket (Poulos et al., 1987). Conservation at the $\mathrm{C}^{369}$, which provides the thiolate ligand to the haem 
TYLH1 MSSSGDARPSQKGILLPAARANDTDEAAGRRSIAWPVARTCPFSPPEQYAALRAE-EPIA SOYC MTESTTDPARON---------LDPTSPAPATSFPODRGCPYHPPAGYAPLREGR-PLS SUAC TDTATTPOTT_..............-DAPA-...-FPSNRSCPYOLPDGYAOLRDTPGPL SCA2 MTEMTEKATTFL-........-TSQEAPA---EPADRTCPYQLPTAYSRLRDEPDALR P450 MAGTAD-.....--LPLEM---_-_-_-_RRNGLNPTEELAQVRDRDGVIP

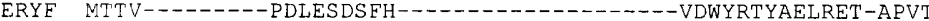
TYLI MTQTLEAEKPPEPERTANSVHPLAQPAGAGARGL------LEWF---ARARAE-APV-

\begin{tabular}{|c|c|c|}
\hline & Sheet & Helix B \\
\hline YLHI & FAEL-WDGAPVW & HVRALLADP-RVSIHP--A-.---KLPRLSPS-DGEAEASR \\
\hline SOYC & RVTL-FDGRPVW & HALARRLLADP-RLSTDRSHP-----DFPVPAERFAGAQRRRV \\
\hline SUAC & RVIL-YDGRQAW & AEAARKLLGDP-RLSSNRTDD------NFPATSPRFEAVRESPQ \\
\hline $\mathrm{SCA} 2$ & PVTL-YDGRRAW & HEAARRLLADP-RLSSDRLHA-----DFPATSPRFKAFRQGSP \\
\hline P450 & VGELY-GAPAFL & EDVRR I FADSNRFSNAHT PMF-- - A I PSGGDVI EDELAAMR \\
\hline ERYF & PYRELGQ-DAW & YDEAKAALSDL-RLSSDPKKKYPGVEVEFPAYLGFPEDVRNYFA \\
\hline LI & -..FWDFSROAW & LDDY-.--L-TVSTNPQL-ESS--DESPVFPVPEELAILMG \\
\hline
\end{tabular}

\section{TYLH 1 S--LLTLDPPDHGALRGHFIPEFGLRRVRDVRPSVEQIVTGLLDDLTARGDEADLLADFA SOYC A--LIGVDDPEHNTQRRMLI PTFSVKRIGALRPRIOETVDRLLDAMEROGPPAELVSAFA SUAC A--EIGLDPPEHGTRRRMTISEFTVKRIKGMRPEVEEVVHGFLDEMLAAGPTADLVSQFA SCA2 I--EIGMDP PEHGTRRRMTI SEFTVKRI KGMRPDVERIVHGFIDDMLAAGPTADLVSQFA P450 AGNL I GLDPPDHTRLRH I LAAE FSVHRLSRLQPRIAEIVDSALDGLEQAGQPADLMDRYA ERYF TN-MGTSDPPTHTRLRKLVSQEFTVRRVEAMRPRVEQITAELLDEVGDSGVV-DIVDRFA TYLI FGTEGGIDPPRHGPLRKLVSQAFTPRRIATLEPRIAEITRGLLDGLREKGQI-DVVSDLA}

\begin{tabular}{|c|c|c|c|}
\hline & HelixE & b Helix F & Helix $\mathrm{G}$ \\
\hline TYLH 1 & LPMATQVICRLLDI & IPYEDRDYFQERTEQATRPA--A------GEE & CALEALLELRDYLD \\
\hline SOYC & LPVESMVICALLG & VPYADHAFEEERSQRLLRGP--G--------ADD & OVNRARDELEEYLG \\
\hline SUAC & LEVPSMVICRLLGV & VPYADHEFFQDASKRLVQST--D------AQS & SALTARNDLAGYLD \\
\hline $\mathrm{SCA} 2$ & ZPVPSMVICHMLG & VPYADHEFEQDASKRLVQAV--D----1---ADS & AVAARDDFERYLD \\
\hline P450 & LPVSLLVLCELLG & VPYADRDELRDRTARLLDLSASA-------EQR & RAVAQRED-RRYMA \\
\hline ERYF & HPLPIKVICELLGV & VDEKYRGEFGRWSSEI LV-------MDPERAEQ & RGQAAREVVNF IL \\
\hline TYLI & YPLPVIVIAELLGI & I PAEDRDLFREWVDVI LNNEGMEYPNLPDDFSET & MGPAIKEWGDYLY \\
\hline
\end{tabular}

$$
\text { Oxygen binding site }
$$

TYLH1 RLISGKTGRESGDGMLGSMVA-QARGGG-LSHADVLDNAVLLLAAGHETTASMVTMSVLV SOYC AIID-RKRAEPGDGLLDELIH-RDHPDGPVDREQLVAFAVILLIAGHETTANMISLGTFT GITT-QFQTEPGAGIVGALVA-DQLANGETDREFISTAMLLITAGHFTTASMTSISVIT SCA2 GLIT-KLESEPGTGLLGKLVT-HQLADGEIDRAELISTALLLLVAGHETTASMTSLSVIT SCA2 GLIT-KLESEPGTGLLGKLVT-HQLADGEIDRAELISTALLLLVAGHFT'TASMTSLSVIT P450 TLVT-RAQEQPGDDLLGI L---ARKIGDNLSTDELISI ISLIMLGGHETTASMIGLSVLA TYLI RRIALK-RETPTDDLMSGLIEAEVEGR-RLTDEEIVNIVALLLTAGHTSSATLLG-NLEL

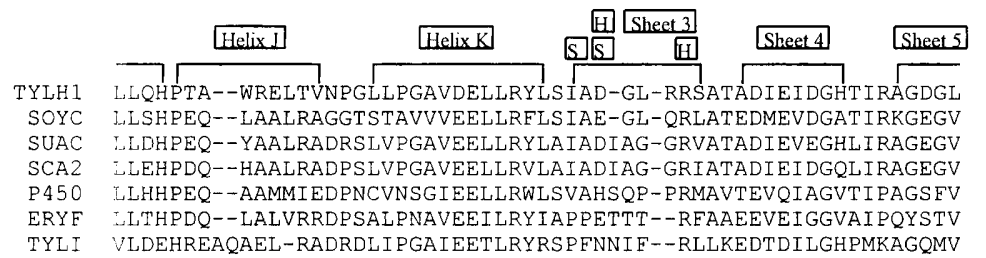

\section{Sheet 5}

$\begin{array}{rll} & & \\ \text { TYLH- } & \text { PALRPTTDVAGLRLKSDSAVFGVYELPVAW } & 420 \\ \text { SOYC } & \text { PGLRLAVPAHEIRHKPGDTIQGLLDLPVAW } & 412 \\ \text { SUAC } & \text { PTLRLAVPVEQLVLRPGTIQGVNELPVTW } & 405 \\ \text { SCA. } & \text { PTLRLAVPVELTLRPGTTIQGVNELPVTW } & 410 \\ \text { P450 } & \text { PDLALS-PSHDVRLRSASIVLGLEELQLTW } & 400 \\ \text { ERYF } & \text { PALSLGIDADDVVWRRSLLLRGIDHLPVRLD-G } & 402 \\ \text { TYLI } & \text { SDYRVEHDEVEFYEEDELTAR---RLPVTVTRH } & 417\end{array}$

Fig. 6. Alignment of amino acid sequences of cytochromes $\mathrm{P} 450$ encoded by the following genes: $t y l H 1$ from $S$. fradiae, soyC from S. griseus, suaC from S. griseolus, sca2 from S. carbophilus, P450 from Rhodococcus fascians, eryf from S. erythraea, and tyll from $S$. fradiae. The alignment was performed as in Fig. 5. The structural features identified (secondary structures, oxygen-binding site and haem pocket) and key amino acids involved in either stabilizing the polypeptide conformation or providing ligands for haem and substrate interactions are from the reported crystal structure for the cytochrome P450cam from Pseudomonas putida (Poulos et al., 1987). Residues conserved in both the oxygen-binding site (Gly-260 and Thr-263) and the haem pocket (Phe-362, Gly-363, Cys-369, and Gly-371) which are invariant in most P450 species are highlighted in bold. Residues marked $O$ (Gln-189, Arg-197, Glu-262 and Ser-266) represent amino acids providing ligands to stabilize the oxygen-binding site. Residues marked H (His-118, Arg-122, Asp-307, Arg311 and His-367) represent amino acids providing hydrogen bonding to the haem propionate groups. Residues marked S (Leu94, Gly-102, Thr-196, Leu-255, Ala-258, lle305 and Asp-307) represent amino acids having extensive protein-substrate contacts. group, was also observed (Fig. 6). Since tylH mutants were unable to oxidize the C-23 methyl position of the lactone (Baltz \& Seno, 1981; Bauer et al., 1988), the cytochrome $\mathrm{P} 450$ and ferredoxin could be responsible for the oxidation at the C-23 methyl position of the lactone. Consequently, we propose the designation of ORF7 as $t y l H 1$. The $t y l H 1$ and $t y l H 2$ gene products strongly resemble the enzymic complex found in bio- 
degradative and biosynthetic pathways of actinomycctes (Sariaslani \& Omer, 1992). However, we have not found the third component of this system, a ferredoxin reductase, in the region of the tylosin biosynthetic cluster analysed. The frequent absence of these reductases within P450-ferredoxin operons agrees with the data presented by O'Keefe \& Harder (1991).

ORF8 (ty/f). The product of this ORF (255 residues, $28.6 \mathrm{kDa}, \mathrm{pI} 4.6$ ) includes the partial 38 amino acid sequence of the $\mathrm{N}$-terminal edge of the macrocin $\mathrm{O}$ methyltransferase encoded by $t y l F$ (GenBank accession number J03008) (Fishman et al., 1987). It also showed similarity to the product of the $m y c F$ gene from Micromonospora griseorubida (Fig. 4), encoding the enzyme mycinamicin III O-methyltransferase, involved in the biosynthesis of the macrolide antibiotic mycinamicin (Inouye et al., 1994b). These data confirmed that ORF8 corresponds to the $t y l F$ gene encoding macrocin O-methyltransferase. Curiously, the similarity to the methyltransferase reported to be encoded by the tylM 1 gene of the tylosin cluster is not significant (Gandecha et al., 1997). The function of the tylF product, which catalyses the conversion of macrocin into tylosin, was previously analysed in cell-free extracts from a tylosinproducing strain of $S$. fradiae and its mutants (Seno \& Baltz, 1981). This enzymic conversion is known to be the major bottleneck in tylosin biosynthesis due to the large amounts of macrocin accumulated in fermentation broths. The $t y l F$ gene has been introduced into a tylosinproducing strain of $S$. fradiae on a self-replicating plasmid; conversion of macrocin to tylosin was more efficient, but the overall production of tylosin together with its immediate precursors was reduced (Cox 8 z Seno, 1990). However, Solenberg et al. (1996) described the insertion of a second copy of the $t y l F$ gene into the $S$. fradiae genome by transposon exchange, resulting in a $30 \%$ increase in tylosin yield. It has been reported and assumed that the methylation of the two hydroxyl groups at the $2^{\prime \prime \prime}-\mathrm{OH}$ and $3^{\prime \prime \prime}-\mathrm{OH}$ positions of 6 . deoxyallose is catalysed by separate enzymes with narrow substrate specificity (Seno \& Baltz, 1982). As we: describe below, the expression of additional copies of the $t y l F$ gene in $S$. fradiae results in a dramatic macrocin depletion.

ORF9 (tyl). The predicted polypeptide (205 residues, $22 \cdot 8 \mathrm{kDa}$, pI 6.7 ) showed similarity to many proteins with TDP-4-keto-6-deoxyglucose 3,5-epimerase activity. The closest similarity $(50 \%)$ was found to the homologous proteins encoded by the strM genes from Streptomyces glaucescens (Fig. 4) and Streptomyces griseus (Pissowotzki et al., 1991). An epimerase is required in the biosynthetic pathway to convert TDPglucose to mycinose and mycarose. We propose to allocate ORF9 to the $t y l J$ gene, which would code for an epimerase activity involved in mycinose biosynthesis. This result is consistent with the description of the $t y l j$ locus postulated to be involved in the biosynthesis or attachment of 6-deoxy-D-allose, accumulating demycinosyltylosin (Fishman et al., 1987; Baltz \& Seno, 1988).
The glycosyltransferase activity encoded by $t y l N$ and involved in mycinose biosynthesis showed no significant similarity to the protein with same function encoded by tylM2 (Gandecha et al., 1997) and involved in the biosynthesis of mycaminose. However, tylJ encoded a protein with $43.0 \%$ similarity to the product of eryBVII, which is thought to encode a 3,5-epimerase involved in the biosynthesis of the erythromycin sugar L-mycarose (Summers et al., 1997).

ORF10 (tyIP). The deduced product $(658$ residues, $71.5 \mathrm{kDa}, \mathrm{pI} 7 \cdot 1$ ) showed similarity to several acyl-CoA oxidases $(26.6 \%$ to Myxococcus xanthus acyl-CoA oxidase), some of them located in the peroxisomes of eukaryotic organisms. These enzymes catalyse the initial step in fatty acid $\beta$-oxidation, introducing a double bond into the saturated carbon chain bound to coenzyme A. Synthesis of tylactone appears to be carried out by a mechanism similar to the long-chain fatty acid biosynthesis: condensation of simple carboxylated CoA derivatives of acetate, propionate and butyrate (Robinson, 1991). A crotonyl-CoA reductase encoded by the ccr gene, that converts acetoacetyl-CoA to butyryl-CoA, has been reported to be involved in the supply of precursors for tylactone biosynthesis (Gandecha et al., 1997). TylP could catalyse the synthesis of crotonyl-CoA from butyryl-CoA and Ccr could reduce it back. Complementary work is required to determine whether the tylP putative product performs some of these functions.

ORF11 (tylQ). The protein deduced (224 residues, $24.7 \mathrm{kDa}, \mathrm{pI} 7.9$ ) was named TylQ and showed significant similarity to several receptors of regulatory factors such as FarA from Streptomyces sp. (Waki et al., 1997) (Fig. 4), BarA from Streptomyces virginiae (Okamoto et al., 1995) and A-factor receptor from Streptomyces griseus (Onaka et al., 1995). A-factor is a bacterial pheromone widely employed to trigger morphological development or antibiotic biosynthesis in Streptomyces, which is thought to elicit these effects through interactions with A-factor-binding proteins (Hara \& Beppu, 1982; Yamada et al., 1987; Horinouchi $\&$ Beppu, 1990). Butyrolactone receptors are a subgroup of the tet $R$ family of regulatory proteins which have a common $\alpha$-helix-turn- $\alpha$-helix (HTH) DNAbinding motif for switching off the expression of key genes. This HTH motif was found at the N-terminal edge of TylQ $\left({ }^{25}\right.$ GYEATTIAEILKRSGVTKGALYFHFTSKELQ $\left.{ }^{54}\right)$. The potential involvement of TylQ in regulation of tylosin production is proposed. To our knowledge, this is the first report of a regulatory gene within a type I polyketide biosynthetic gene cluster.

\section{Functional characterization of $\operatorname{tr} B$ and $t y / F$}

In order to express the $t r B$ gene in several Streptomyces strains, a $1.4 \mathrm{~kb} K p n \mathrm{I}-\mathrm{SacII}$ fragment including this tylosin-resistance gene was cloned in the shuttle vector pULVK99 (Chary et al., 1997) generating the plasmid pALF250, which carries thiostrepton-, kanamycin- and 
tylosin-resistance markers. In parallel, the minimal inhibitory concentration of tylosin was determined for S. lividans ATCC $1326\left(25 \mu \mathrm{g} \mathrm{ml}^{-1}\right)$, S. parvulus DSM $40048\left(25 \mu \mathrm{g} \mathrm{ml}^{-1}\right), S$. coelicolor DSM $40233(10 \mu \mathrm{g}$ $\left.\mathrm{ml}^{-1}\right)$ and S. clavuligerus ATCC $27064\left(70 \mu \mathrm{g} \mathrm{ml} \mathrm{m}^{-1}\right)$. Once the selection conditions were established, pALF250 was used to transform the above-mentioned hosts by standard methods (Hopwood et al., 1985) and thiostrepton-resistant transformants were selected on R5 plates. Tylosin resistance level was subsequently checked in these transformants. S. lividans clones were able to grow at $250 \mu \mathrm{g} \mathrm{ml}^{-1}$, some of them reaching a resistance level of $3500 \mu \mathrm{g} \mathrm{ml}^{-1}$. The transformants of $S$. parvulus were able to grow at $200 \mu \mathrm{g} \mathrm{ml}^{-1}$ and a few of them at $1000 \mu \mathrm{g} \mathrm{ml}{ }^{-1}$. Most of the $S$. coelicolor transformants resisted $10 \mu \mathrm{g} \mathrm{ml}^{-1}$, some of them growing at $30 \mu \mathrm{g} \mathrm{ml}^{-1}$. However, the thiostrepton-resistant transformants of $S$. clavuligerus were unable to grow in a tylosin range from 70 to $100 \mu \mathrm{g} \mathrm{ml}^{-1}$. In addition, transformants of $S$. lividans and $S$. parvulus were directly selected on R5 plates using tylosin concentrations of $250 \mu \mathrm{g} \mathrm{ml}^{-1}$ and $200 \mu \mathrm{g} \mathrm{ml}^{-1}$ respectively. Therefore, the $t l r B$ gene can be used as a transformation marker in several Streptomyces species.

The mycinamicin-resistance protein encoded by myr $A$ from $M$. griseorubida showed the highest similarity to the $t r B$ gene product. The myr $A$ gene is unable to confer resistance to erythromycin, and therefore cannot be classified as an MLS resistance gene (Inouye et al., 1994a). In order to analyse this feature with the $\operatorname{tr} B$ gene, its ability to confer erythromycin resistance upon $S$. lividans and S. parvulus was checked. The erythromycin minimal inhibitory concentration was determined for S. lividans $\left(25 \mu \mathrm{g} \mathrm{ml}^{-1}\right)$ and S. parvulus $\left(200 \mu \mathrm{g} \mathrm{ml}^{-1}\right)$, and pALF250 transformants of both species were selected by thiostrepton resistance. All of them were unable to grow in the presence of the above-mentioned inhibitory concentrations of erythromycin. According to these data, the $t r r B$ gene does not seem to belong to the MLS group of resistance determinants.

Furthermore, the tylosin biosynthetic genes $t y l D, t y l H 2$, $t y l \mathrm{H} 1, t y l F$ and $t y l J$ were subcloned as a $5.7 \mathrm{~kb} B a m \mathrm{HI}$ fragment (Fig. 2) in the shuttle vector pULVK99 (Chary et al., 1997), generating the plasmid pALF287. Transformants of $S$. fradiae with additional copies of these genes were selected in R5 plates supplemented with thiostrepton (Hopwood et al., 1985). The effect of these genes on tylosin production was tested by flask fermentation of the transformants in tylosin-producing conditions (Baltz \& Seno, 1981). Around 40 transformants were analysed; they showed significant increases of tylosin production $(10-50 \%)$ and dramatic macrocin depletion (15-30-fold). These results are in agreement with those of Baltz et al. (1997). A remarkable variability in terms of tylosin production level was detected among the transformants tested, probably due to the use of a non-integrative vector instead of the stable insertion by transposon exchange described by Solenberg et al. (1996) or by insertion into a neutral site (Baltz et al., 1997).

\section{The mycinose biosynthetic pathway}

Many antibiotics contain partially deoxygenated sugar components essential for biological activity. Since mycinose, mycarose and mycaminose are key components of the tylosin molecule, identification of the genes involved in their biosynthesis and knowledge of the enzymic pathway leading to them are fundamental for the construction of recombinant strains overproducing this antibiotic. All three of these sugars seem to be synthesized from glucose, which is converted into TDPglucose by TDP-glucose synthase (Grisebach, 1978), encoded by tylA1 (Merson-Davies \& Cundliffe, 1994). Subsequently, TDP-glucose is converted into TDP-4keto-6-deoxy-D-glucose, a common intermediate in the biosynthetic pathway of most deoxysugars (Liu \& Thorson, 1994). This irreversible intramolecular oxidation-reduction is catalysed by an $\mathrm{NAD}^{+}$-dependent TDP-glucose dehydratase. According to Merson-Davies \& Cundliffe (1994), the tylA2 gene is responsible for this enzymic conversion in the three tylosin sugars.

The genes involved in mycaminose biosynthesis have recently been described (Gandecha et al., 1997) and only an isomerase-encoding gene remains unidentified in the route. Likewise, another pathway was proposed for the formation of mycarose, a sugar component of both tylosin and erythromycin antibiotics (Liu \& Thorson, 1994; Summers et al., 1997; Gaisser et al., 1997, 1998; Salah-Bey et al., 1998). Five eryB genes (eryBVII, eryBVI, eryBII, eryBIII and eryBIV) have been proposed to accomplish the biosynthetic pathway from TDP-4-keto6-deoxyhexose to TDP-mycarose in S. erythraea (Gaisser et al., 1998; Salah-Bey et al., 1998). A similar pathway with homologous genes should exist in $S$. fradiae.

According to previous studies on complementation of blocked mutants (Fishman et al., 1987; Baltz \& Seno, 1981), a portion of the DNA region described in this work includes genes involved in mycinose biosynthesis. Complementation of idiotrophic mutants blocked in the $t y l D$ and tylJ loci showed that they were related to the biosynthesis or attachment of mycinose, whereas tylE and $t y l F$ encoded enzymes responsible for methylation of the 2-hydroxy and 3-hydroxy positions of the attached 6-deoxy-D-allose residue (Baltz \& Seno, 1988). We propose a putative route for the biosynthesis of mycinose (Fig. 1) where TDP-4-keto-6-deoxy-D-glucose, the product of the dehydratase encoded by tylA2, would be converted to 6-deoxy-D-allose by $3^{\prime}$ epimerization and subsequent reduction of the 4-keto position to an alcohol. Such an epimerase-reductase has been described in the L-fucose biosynthetic route (Chang et al., 1988). The epimerase activity would be encoded by $t y l J$, whereas the product of $t y l D$, which showed similarity to conserved motifs of reductases, could catalyse the subsequent conversion to 6-deoxy-D-allose. This sugar would be attached to the $\mathrm{C}-23 \mathrm{OH}$ of the tylactone ring by the glycosyltransferase encoded by $t y l N$. In the final steps of the pathway, two methyl groups are incorporated into the $2^{\prime \prime \prime}-\mathrm{OH}$ and $3^{\prime \prime \prime}-\mathrm{OH}$ positions of the 
6-deoxy-D-allose residue, to transform this compound into mycinose, yielding tylosin. The two methyltransferases would be encoded by $t y l E$ and $t y l F$ respectively.

The complete characterization of the biosynthetic gene cluster will provide a very important tool for the improvement of tylosin production. The development of some antibiotic-producing strains by increasing the copy number of the biosynthetic genes has been reported (Díez et al., 1997). This suggests that transforming tylosin-producing micro-organisms with these biosynthetic genes would improve tylosin productivity. Moreover, an outstanding application of the establishment of the genetic organization of the $t y l$ cluster is the synthesis of heterospecific recombinant strains to produce novel hybrid antibiotics (Baltz, 1995). Hybrid antibiotics could be constructed using genes from different clusters (actinorhodin, tetracenomycin, granaticin, etc.). With this approach, one can envision the possibility of producing large numbers of novel macrolide antibioric structures which might be further modified chemically.

\section{ACKNOWLEDGEMENTS}

The authors thank J. A. González, P. Merino, M. Sandoval and M. T. García for their excellent technical assistance and J. Velasco for helpful comments. R. Fouces was supported by a fellowship of the Spanish Ministry of Education and Science.

\section{REFERENCES}

Asano, Y., Ito, H., Dairi, T. \& Kato, Y. (1996). An alkaline D-stereospecific endopeptidase with $\beta$-lactamase activity from Bacillus cereus. J Biol Chem 271, 30256-30262.

Baltz, R. H. (1995). Gene expression in recombinant Streptomyces. In Gene Expression in Recombinant Microorganisms, pp. 309-381. Edited by A. Smith. New York: Marcel Dekker.

Baltz, R. H. \& Seno, E. T. (1981). Properties of Streptomyces fradiae mutants blocked in biosynthesis of the macrolide antibiotic tylosin. Antimicrob Agents Chemother 20, 214-225.

Baltz, R. H. \& Seno, E. T. (1988). Genetics of Streptomyces fradiae and tylosin biosynthesis. Annu Rev Microbiol 42, 547-574.

Baltz, R. H., Seno, E. T., Stonesifer, J. \& Wild, G. M. (1983). Biosynthesis of the macrolide antibiotic tylosin. A preferred pathway from tylactone to tylosin. J Antibiot 36, 131-141.

Baltz, R. H., McHenney, M. A., Cantwell, C. A., Queener, S. W. \& Solenberg, P. J. (1997). Applications of transposition mutagenesis in antibiotic producing streptomycetes. Antonie Leeuwenboek 71, 179-187.

Bauer, N. J., Kreuzman, A. J., Dotzlaf, J. E. \& Yeh, W. K. (1988). Purification, characterization, and kinetic mechanism of $S$ adenosyl-L-methionine:macrocin O-methyltransferase from Streptomyces fradiae. J Biol Chem 263, 15619-15625.

Bauer, A. J., Rayment, I., Frey, P. A. \& Holden, H. M. (1992). The molecular structure of UDP-galactose 4-epimerase fronı Escherichia coli determined at $2.5 \AA$ resolution. Proteins 12 , 372-381.

Beckmann, R. J., Cox, K. \& Seno, E. T. (1989). A cluster of tylosin biosynthetic genes is interrupted by a structurally unstable segment containing four repeated sequences. In Genetics and Molecular Biology of Industrial Microorganisms, pp. 176-186.
Edited by C. L. Hershberger, S. W. Queener \& G. Hegeman. Washington, DC: American Society for Microbiology.

Bibb, M. J., Findlay, P. R. \& Johnson, M. W. (1984). The relationship between base composition and codon usage in bacterial genes and its use for the simple and reliable identification of protein coding sequences. Gene 30, 157-166.

Birmingham, V. A. \& Seno, E. T. (1988). A new tylosin resistanceconferring gene, designated $t / r B$, for use in Streptomyces and other microorganisms. European Patent Application 0251510A1.

Birmingham, V. A., Cox, K. L., Larson, J. L., Fishman, S. E., Hershberger, C. L. \& Seno, E. T. (1986). Cloning and expression of a tylosin resistance gene from a tylosin-producing strain of Streptomyces fradiae. Mol Gen Genet 204, 532-539.

Bruschi, M. \& Guerlesquin, F. (1988). Structure, function and evolution of bacterial ferredoxins. FEMS Microbiol Rev 4, 155-175.

Chang, S., Duerr, B. \& Serif, G. (1988). An epimerase-reductase in L-fucose synthesis. J Biol Chem 263, 1693-1697.

Chary, V. K., de la Fuente, J. L., Liras, P. \& Martin, J. F. (1997). amy as a reporter gene for promoter activity in Nocardia lactamdurans: comparison of promoters of the cephamycin cluster. Appl Environ Microbiol 63, 2977-2982.

Coque, J. J., Liras, P. \& Martín, J. F. (1993). Genes for a $\beta$ lactamase, a penicillin binding protein and a transmembrane protein are clustered with the cephamycin biosynthetic genes in Nocardia lactamdurans. EMBO J 12, 631-639.

Cox, K. L. \& Seno, E. T. (1990). Maintenance of cloned tylosin biosynthetic genes in Streptomyces fradiae on freely-replicating and integrative plasmid vectors. J Cell Biochem Suppl 14A, 93.

Cox, K. L., Fishman, S. E., Hershberger, C. L. \& Seno, E. T. (1997). Method for increasing the antibiotic-producing ability of antibiotic-producing microorganisms. United States Patent 5672497.

Crespi, M., Vereecke, D., Temmerman, W., Van Montagu, M. \& Desomer, J. (1994). The fas operon of Rhodococcus fascians encodes new genes required for efficient fasciation of host plants. $J$ Bacteriol 176, 2492-2501.

Criado, L. M., Martin, J. F. \& Gil, J. A. (1993). The pab gene of Streptomyces griseus, encoding $p$-aminobenzoic acid synthase, is located between genes possibly involved in candicidin biosynthesis. Gene 126, 135-139.

Cundliffe, E., Merson-Davies, L. A. \& Kelemen, G. H. (1993). Aspects of tylosin production and resistance in Streptomyces fradiae. In Industrial Microorganisms: Basic and Applied Molecular Genetics, pp. 235-243. Edited by R. H. Baltz, G. D. Hegeman \& P. L. Skatrud. Washington, DC: American Society for Microbiology.

Díez, B., Mellado, E., Rodríguez, M., Fouces, R. \& Barredo, J. L. (1997). Recombinant microorganisms for industrial production of antibiotics. Biotechnol Bioeng 55, 216-226.

Distler, J., Mansouri, K. \& Piepersberg, W. (1985). Streptomycin biosynthesis in Streptomyces griseus. Adjacent genomic location of biosynthetic genes and one of two streptomycin resistance genes. FEMS Microbiol Lett 30, 151-154.

Duez, C., Piron-Fraipont, C., Joris, B., Dusart, J., Urdea, M. S., Martial, J. A., Frère, J. M. \& Ghuysen, J. M. (1987). Primary structure of the Streptomyces R61 extracellular DD-peptidase. Cloning into Streptomyces lividans and nucleotide sequence of the gene. Eur J Biochem 162, 509-518.

Epp, J. K., Burgett, S. G. \& Schoner, B. E. (1987). Cloning and nucleotide sequence of a carbomycin-resistance gene from Streptomyces thermotolerans. Gene 53, 73-83.

Fishman, S. E., Cox, K., Larson, J. L., Reynolds, P. A., Seno, E. T., 
Yeh, W-K., Van Frank, R. \& Hershberger, C. L. (1987). Cloning genes for the biosynthesis of a macrolide antibiotic. Proc Natl Acad Sci USA 84, 8248-8252.

Fujisawa, Y. \& Weisblum, B. (1981). A family of r-determinants in Streptomyces spp. that specifies inducible resistance to macrolide, lincosamide and streptogramin type B antibiotics. J Bacteriol 146, 621-631.

Gaisser, S., Bohm, G. A., Cortés, J. \& Leadlay, P. F. (1997). Analysis of seven genes from the eryAI-eryK region of the erythromycin biosynthetic gene cluster in Saccharopolyspora erythraea. Mol Gen Genet 256, 239-251.

Gaisser, S., Bohm, G. A., Doumith, M., Raynal, M. C., Dhillon, N., Cortés, J. \& Leadlay, P. F. (1998). Analysis of eryBI, eryBIII and ery $B V I I$ from the erythromycin biosynthetic gene cluster in Saccharopolyspora erythraea. Mol Gen Genet 258, 78-88.

Gandecha, A. R., Large, S. L. \& Cundliffe, E. (1997). Analysis of four tylosin biosynthetic genes from the tylLM region of the Streptomyces fradiae genome. Gene 184, 197-203.

García-Domínguez, M., Martín, J. F., Mahron, B., Demain, A. L. \& Liras, P. (1987). Efficient plasmid transformation of the betalactam producer Streptomyces clavuligerus. Appl Environ Microbiol 53, 1376-1381.

Grisebach, H. (1978). Biosynthesis of macrolide antibiotics. In: Antibiotics and Other Secondary Metabolites. Biosynthesis and Production, pp. 113-127. Edited by R. Hütter, T. Leisinger, J. Nüesch \& W. Wehrli. London: Academic Press.

Hanahan, D. (1983). Studies on transformation of Escherichia coli with plasmids. J Mol Biol 166, 557-580.

Hara, O. \& Beppu, T. (1982). Mutants blocked in streptomycin production in Streptomyces griseus - the role of A-factor. $J$ Antibiot 35, 349-358.

Hara, O. \& Hutchinson, C. R. (1992). A macrolide 3-O-acyltransferase gene from the midecamycin-producing species Streptomyces mycarofaciens. J Bacteriol 174, 5141-5144.

Hopwood, D. A., Bibb, M. J., Chater, K. F., Kieser, T., Bruton, C. J., Kieser, H. M., Lydiate, D. J., Smith, C. P., Ward, J. M. \& Schrempf, H. (1985). Genetic Manipulation of Streptomyces: A Laboratory Manual. Norwich, UK: John Innes Foundation.

Horinouchi, S. \& Beppu, T. (1990). Autoregulatory factors of secondary metabolism and morphogenesis in actinomycetes. Crit Rev Biotechnol 10, 191-204.

Ingrosso, D., Fowler, A. V., Bleibaum, J. \& Clarke, S. (1989). Sequence of the $\mathrm{D}$-aspartyl/L-isoaspartyl protein methyltransferases from human erythrocytes. Common sequence motifs for the protein, DNA, RNA and small molecule $S$-adenosylmethionine dependent methyltransferases. J Biol Chem 264, 20131-20139.

Inouye, M., Morohoshi, T., Horinouchi, S. \& Beppu, T. (1994a). Cloning and sequences of two macrolide-resistance-encoding genes from mycinamicin-producing Micromonospora griseorubida. Gene 141, 39-46.

Inouye, M., Suzuki, H., Takada, Y., Muto, N., Horinouchi, S. \& Beppu, T. (1994b). A gene encoding mycinamicin III O-methyltransferase from Micromonospora griseorubida. Gene 141, 121-124.

Jensen, A. L., Darken, M. A., Schultz, J. S. \& Shay, A. J. (1964). Relomycin: flask and tank fermentation studies. In Antimicrobial Agents and Chemotherapy. Edited by J. C. Sylvester. Washington, DC: American Society for Microbiology.

Kageyama, B., Okazaki, M. \& Shibasaki, I. (1971). Mode of action of tylosin (II). J Ferment Technol 49, 747-758.

Kramer, W., Drutsa, V., Jansen, H. W., Kramer, B., Pflugfelder, M.
\& Fritz, H. H. (1984). The gapped duplex method DNA approach to oligonucleotide-directed mutation construction. Nucleic Acids Res 12, 9441-9456.

Kreuzman, A. J., Turner, J. R. \& Yeh, W. -K. (1988). Two distinctive $O$-methyltransferases catalyzing penultimate and terminal reactions of macrolide antibiotic (tylosin) biosynthesis. J Biol Chem 263, 15626-15633.

Liu, H.-W. \& Thorson, J. S. (1994). Pathways and mechanisms in the biogenesis of novel deoxysugars by bacteria. Annu Rev Microbiol 48, 223-256.

Merson-Davis, L. A. \& Cundliffe, E. (1994). Analysis of five tylosin biosynthetic genes from the tyllBA region of the Streptomyces fradiae genome. Mol Microbiol 13, 349-355.

Okamoto, S., Nakamura, K., Nihira, T. \& Yamada, Y. (1995). Virginiae butanolide binding protein from Streptomyces virginiae. J Biol Chem 270, 12319-12326.

O'Keefe, D. P. \& Harder, P. A. (1991). Occurrence and biological function of cytochrome P450 monooxygenase in the actinomycetes. Mol Microbiol 5, 2099-2105.

Omer, C. A., Lenstra, R., Little, P. J., Dean, C. R., Tepperman, J. M., Leto, K. J., Romesser, J. A. \& O'Keefe, D. P. (1990). Genes for two herbicide-inducible cytochromes P-450 from Streptomyces griseolus. J Bacteriol 172, 3335-3345.

Onaka, H., Ando, N., Nihira, T., Yamada, Y., Beppu, T. \& Horinouchi, S. (1995). Cloning and characterization of the Afactor receptor gene from Streptomyces griseus. J Bacteriol 177, 6083-6092.

Pape, H. \& Brillinger, R. H. (1973). Metabolic products of microorganisms. 113. Biosynthesis of thymidine diphosphomycarose in a cell-free system from Streptomyces rimosus. Arch Microbiol 88, 25-35.

Pissowotzki, K., Mansouri, K. \& Piepersberg, W. (1991). Genetics of streptomycin production in Streptomyces griseus: molecular structure and putative function of genes strELMB2N. Mol Gen Genet 231, 113-123.

Poulos, T. L., Finzel, B. C. \& Howard, A. J. (1987). High-resolution

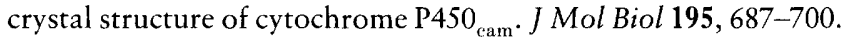

Richardson, M. A., Kuhstoss, S., Solenberg, P., Schaus, N. A. \& Rao, R. N. (1987). A new shuttle cosmid vector, pKC505, for streptomycetes: its use in the cloning of three different spiramycin-resistance genes from a Streptomyces ambofaciens library. Gene 61, 231-241.

Robinson, J. (1991). Polyketide synthase complexes: their structure and function in antibrotic biosynthesis. Philos Trans $R$ Soc Lond Ser B Biol Sci 332, 107-114.

Rosteck, P. R., Reynolds, P. A. \& Hersberger, C. L. (1991). Homology between proteins controlling Streptomyces fradiae tylosin resistance and ATP-binding transport. Gene 102, 27-32.

Salah-Bey, K., Doumith, M., Michel, J. M., Haydock, S., Cortés, J., Leadlay, P. F. \& Raynal, M. C. (1998). Targeted gene inactivation for the elucidation of deoxysugar biosynthesis in the erythromycin producer Saccharopolyspora erythraea. Mol Gen Genet 257, 542-553.

Sambrook, J., Fritsch, E. F. \& Maniatis, T. (1989). Molecular Cloning: a Laboratory Manual. Cold Spring Harbor, NY: Cold Spring Harbor Laboratory.

Sariaslani, F. S. \& Omer, C. A. (1992). Actinomycete cytochromes P-450 involved in oxidative metabolism: biochemistry and molecular biology. Crit Rev Plant Sci 11, 1-16.

Seno, E. T. \& Baltz, R. H. (1981). Properties of $S$-adenosyl-Lmethionine: macrocin O-methyltransferase in extracts of Streptomyces fradiae strains which produce normal or elevated levels of 
tylosin and in mutants blocked in specific O-methylations. Antimicrob Agents Chemother 20, 370-377.

Seno, E. T. \& Baltz, R. H. (1982). S-Adenosyl-L-methionine macrocin $O$-methyltransferase activities in a series of Strepto. myces fradiae mutants that produce different levels of the macrolide antibiotic tylosin. Antimicrob Agents Chemother 21. 758-763.

Seno, E. T., Pieper, R. L. \& Huber, F. M. (1977). Terminal stages in the biosynthesis of tylosin. Antimicrob Agents Chemother 11, $455-461$.

Solenberg, P. J., Cantwell, C. A., Tietz, A. J., Gilvray, D. M., Queener, S. W. \& Baltz, R. H. (1996). Transposition mutagenesis in Streptomyces fradiae: identification of a neutral site for stable insertion of DNA by transposon exchange. Gene 168, 67-72.

Solenberg, P. J., Matsushima, P., Stack, D. R., Wilkie, S. C., Thompson, R. C. \& Baltz, R. H. (1997). Production of hybrid glycopeptide antibiotics in vitro and in Streptomyces toyocaensis. Chem Biol 4, 195-202.

Summers, R. G., Donadio, S., Staver, M. J., Wendt-Pienkowski, E., Hutchinson, C. R. \& Katz, L. (1997). Sequencing and mutagenesis of genes from the erythromycin biosynthetic gene cluster of Saccharopolyspora erythraea that are involved in L-mycarose and D-desosamine production. Microbiology 143, 3251-3262.

Trower, M. K., Lenstra, R., Omer, C., Buchholz, S. E. \& Sariaslani, F. S. (1992). Cloning, nucleotide sequence determination and expression of the genes encoding cytochrome P-450 soy (soyC) and ferredoxin $_{\text {soy }}($ soyB) from Streptomyces griseus. Mol Microbiol 6, $2125-2134$.

Waki, M., Nihira, T. \& Yamada, Y. (1997). Cloning and characterisation of the gene $(\operatorname{far} A)$ encoding the receptor for an extracellular regulatory factor (IM-2) from Streptomyces sp. strain FRI-5. J Bacteriol 179, 5131-5137.

Warnecke, D. C., Baltrusch, M., Buck, F., Wolter, F. P. \& Heinz, E. (1997). UDP-glucose-sterol glucosyltransferase: cloning and functional expression in Escherichia coli. Plant Mol Biol 35, 597-603.

Watanabe, I., Nara, F. \& Serizawa, N. (1995). Cloning, characterisation and expression of the gene encoding cytochrome P450sca2 from Streptomyces carbophilus involved in production of pravastatin, a specific HMG-CoA reductase inhibitor. Gene 163, 81-85.

Wierenga, R. K. \& Hol, W. G. (1983). Predicted nucleotide-binding properties of $\mathrm{p} 21$ protein and its cancer-associated variant. Nature 302, 842-844.

Wilson, V. T. \& Cundliffe, E. (1998). Characterization and targeted disruption of a glycosyltransferase gene in the tylosin producer, Streptomyces fradiae. Gene 214, 95-100.

Yamada, Y., Sugamura, K., Kondo, K., Yanagimoto, M. \& Okada, H. (1987). The structure of inducing factors for virginiamycin production in Streptomyces virginiae. J Antibiot 40, 496-504.

Ylihonko, K., Tuikkanen, J., Jussila, S., Cong, L. \& Mäntsălä, P. (1996). A gene cluster involved in nogalamycin biosynthesis from Streptomyces nogalater: sequence analysis and complementation of early-block mutations in the anthracycline pathway. Mol Gen Genet 251, 113-120.

Zalacain, M. \& Cundliffe, E. (1991). Cloning of $t h D$, a fourth resistance gene, from the tylosin producer, Streptomyces fradiae. Gene 97, 137-142.

Received 9 September 1998; revised 18 November 1998; accepted 4 January 1999. 